Case Report

\title{
Bilateral choanal atresia
}

\author{
Luh Putu Lusy Indrawati, Muhammad Syafiq Riski, Ranita Parjaman \\ Department of Otorhinolaryngology-Head and Neck Surgery \\ Faculty of Medicine, Public Health and Nursing \\ Universitas Gadjah Mada/Dr. Sardjito Hospital, Yogyakarta
}

\begin{abstract}
Background: Choanal atresia is an uncommon anomaly that causes upper airway obstruction in newborns, with a frequency of 1 in 5000 to 7000 births. The definitive treatment is surgery. Purpose: To inform the diagnosis and management of a bilateral choanal atresia. Case report: A 2-months-old girl with a diagnosis of bilateral choanal atresia. The patient underwent transnasal endoscopic repair of choanal atresia under general anesthesia. Clinical question: Could transnasal endoscopic repair of choanal atresia followed by stenting, provide better result than other approaches? Review method: Literature search using keywords 'choanal atresia' AND 'bilateral' AND 'membranous' AND 'endoscopic' AND 'surgery' AND 'stent' was conducted through PubMed, Science Direct, and The Cochrane Library. Result: The search obtained 34 articles concerning choanal atresia. Selection based on inclusion and exclusion criteria, found 15 articles were relevant with the topic. Conclusion: A baby girl came with bilateral choanal atresia. The diagnosis was established by nasoendoscopy, supported by CT imaging. She underwent transnasal endoscopic repair of the stenotic choanae under general anesthesia.
\end{abstract}

Keywords: bilateral choanal atresia, transnasal endoscopic surgery, congenital nasal airway anomaly

\begin{abstract}
ABSTRAK
Latar belakang: Atresia koana merupakan kelainan pada neonatus yang jarang terjadi, yang dapat menyebabkan obstruksi jalan napas atas. Frekuensi kasus sebanyak 1 dari 5000 sampai 7000 kelahiran. Tatalaksana definitif pada kasus atresia koana adalah tindakan operatif. Tujuan: Memberikan informasi mengenai diagnosis dan tatalaksana atresia koana bilateral. Laporan kasus: Bayi berusia 2 bulan dengan diagnosis atresia koana bilateral. Tatalaksana pada kasus ini adalah operasi membuka koana dengan pendekatan endoskopi transnasal. Pertanyaan klinis: Apakah tatalaksana operasi perbaikan atresia koana dengan pendekatan transnasal endoskopi yang diikuti dengan pemasangan stent lebih baik dibandingkan dengan pendekatan lain? Telaah literatur: Dilakukan penelusuran menggunakan kata kunci 'choanal atresia' DAN 'bilateral' DAN 'membranous' DAN 'endoscopic' DAN 'surgery' DAN 'stent' pada beberapa sumber data seperti PubMed, Science Direct, dan The Cochrane Library. Hasil: Didapatkan 34 artikel yang membahas atresia koana. Melalui kriteria inklusi dan eksklusi diperoleh 15 artikel yang relevan dengan topik. Kesimpulan: Telah dilaporkan pasien dengan diagnosis atresia koana bilateral. Diagnosis ditegakkan melalui endoskopi transnasal dan CT scan. Dilakukan perbaikan koana menggunakan pendekatan endoskopi transnasal, dengan anestesi umum.
\end{abstract}

Kata kunci: atresia koana bilateral, endoskopi transnasal, kelainan kongenital hidung

Correspondence address: Luh Putu Lusy Indrawati, Department of Otorhinolaryngology Head and Neck Surgery, Faculty of Medicine, Public Health and Nursing Universitas Gadjah Mada/Dr. Sardjito Hospital, Yogyakarta. Email: indrawatilusy@yahoo.co.id 


\section{INTRODUCTION}

Choanal atresia is the developmental failure of the posterior nasal cavity to communicate with the nasopharynx. ${ }^{1}$ Choanal atresia is relatively uncommon but wellrecognized as congenital nasal airway abnormality, that could have various clinical presentations ranging from acute airway obstruction to chronic recurrent sinusitis. This disease entity was first described by Roederer in 1755 while Oto et al. further characterized the anomaly in relation to the deformity of the palatine bones in $1829 .{ }^{2}$

Choanal atresia is found in newborns, with a frequency of 1 in 5000 to 7000 births. It occurs twice more common in female than male infants, and is frequently unilateral and right-sided than bilateral. ${ }^{2}$ The choana could be occluded by purely membranous soft tissue, or bone, or combination of bone and membranous soft tissue. ${ }^{1}$ It was mentioned that the nature of the atretic plate $90 \%$ contains bony structure, while $10 \%$ only membranous. ${ }^{3}$ Most choanal atresia cases are isolated malformations, but $20-50 \%$ of choanal atresia is associated with other congenital syndrome, named CHARGE syndrome, (consisted of C-coloboma, H-heart defect, A-atresia choana, R-retarded growth and development, G-genital hypoplasia/ genitourinary anomalies, and E-ear anomalies and/or hearing loss). ${ }^{1,4}$

Symptoms of severe airway obstruction and cyclical cyanosis are the classic signs of neonatal bilateral atresia. It is considered as an emergency case, and immediate measures should be taken to secure breathing air passage, by way of inserting intraoral respiratory tube and orogastric tube for feeding. ${ }^{3,5}$

Surgery of choanal atresia aims at complete removal of the atretic plate and assurance of longterm wide choanal patency. ${ }^{6}$ Surgically, choanal atresia could be conducted with various procedures, and the main outcome measures are "patency" of the choana, although there is no standard definition of patency. Even though the treatment techniques for choanal atresia had been extensively reported, there is no consensus on the choice of treatment, as the outcomes are affected by several other conditions, such as feeding patterns and global progress, which in turn, affect the overall development of the patients. Surgical procedures to treat choanal atresia include transnasal puncture, transpalatal resection, and endoscopic resection, which could be supported with stents or without. ${ }^{7}$

\section{CASE REPORT}

A 2 months-old girl was referred to our hospital in July 2020 with chief complaint of dyspnea since birth. This symptom was accompanied by cyanosis that worsened during sleep, noisy breathing, feeding difficulty, and poor weight gain. She was born at 39 weeks gestation by $\mathrm{C}$-section and had 2.300 grams birth weight. The baby did not cry immediately after birth and there was no data of APGAR (Appearance, Pulse, Grimace, Activity and Respiration) score from the previous hospital. Her mother was G4P2A1 with history of failure to progress in labor and oligohydramnion. At the previous hospital, the baby was transferred to the Neonatal Intensive Care Unit (NICU) for further evaluation and management. Echocardiography had been performed with normal result.

The diagnosis of bilateral choanal atresia was established clinically by evidence of failure to pass infant nasogastric tube through the nostril-nasal cavity-pharynx bilaterally.

The baby was immediately transferred to a tertiary hospital for further examination and management. Upon examination, the patient was composmentis, crying and was maintaining 96 percent oxygen saturation without any support. She was tachypnea and making grunting sounds. The air passage was 
found to be equal on both sides without any respiratory adventitious sounds, and neither chest retraction. Computed tomography scan confirmed bilateral membranous choanal atresia, and it was further confirmed by nasal endoscopy.

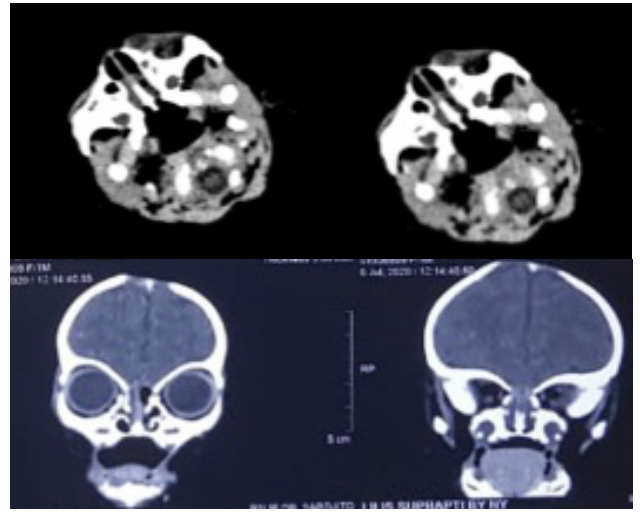

Figure 1. CT scan paranasal sinuses axial and coronal section showing membranous type bilateral choanal atresia.

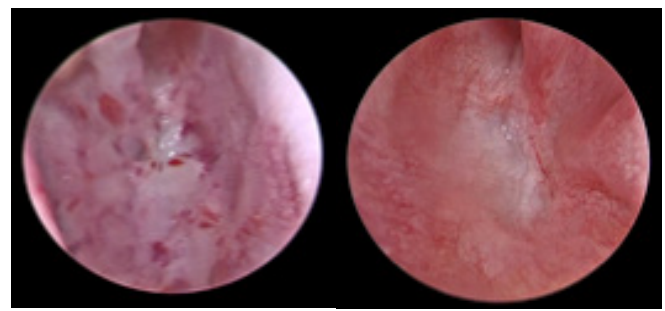

Figure 2. Nasal endoscopic examination of choanae, both sides, showing membranous atretic plate.

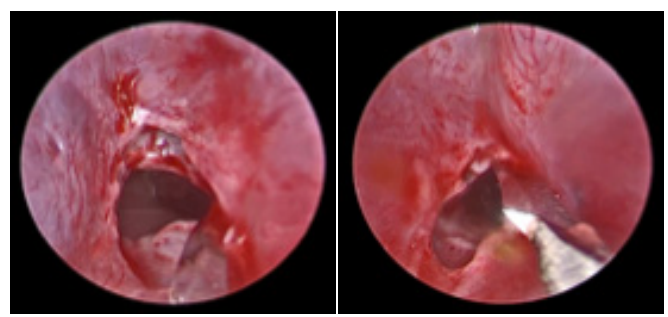

Figure 3. Intraoperative endoscopic view of choanae, both sides, during recanalization

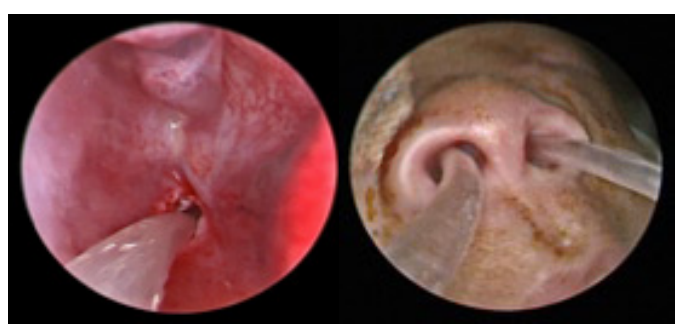

Figure 4. Intraoperative view, showing nasogastric tube insertion to choanae as a stent, placed bilaterally
From the Pediatric Department, there was a suspicion of Young Simpson syndrome with a differential diagnosis of OHDO syndrome. Patient was scheduled for transnasal endoscopic resection of stenotic choanae under general anesthesia on July $17^{\text {th }}$, 2020. After decongestion and suctioning thick mucus from the nasal cavity, both membranous choanae were incised with a sickle knife with the aid of $0^{\circ}$ nasal endoscope. Hemostasis was accomplished intraoperatively, without any need of nasal packing. Post surgery, a size 8 nasogastric tube was cut to suitable length, bent, and placed intranasally, through the choanae into the oropharynx bilaterally. The patient was stable post operatively. There was no intraoperative or postoperative complications, and the patient was discharged on $7^{\text {th }}$ postoperative day. When she was discharged from the hospital, the feeding was continued via orogastric tube, and there was no respiratory difficulty. The nasal stent was removed 8 weeks postoperatively. The baby was followed up until to date with no complaints of recurrent symptoms or any complications.

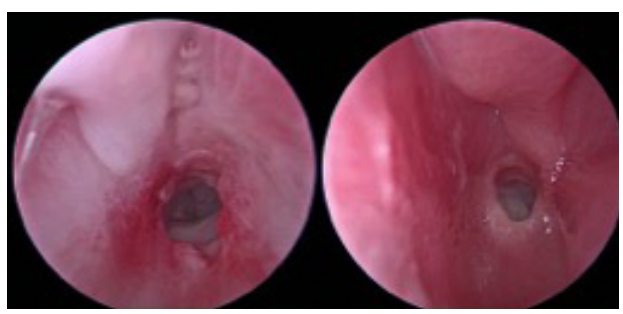

Figure 5. 8 weeks postoperative nasal endoscopic view

\section{REVIEW METHOD}

Literature search used keywords 'choanal atresia' AND 'bilateral' AND 'membranous' AND 'endoscopic' AND 'surgery' AND 'stent'. Searching result on PubMed, ScienceDirect, The Cochrane Library and Google Scholar obtained 8 journals in PubMed, 26 journals at Science Direct, and 0 articles in the Cochrane Library. 


\section{RESULT}

From literature searching, it was obtained 34 articles. Selection based on inclusion and exclusion criteria, found 15 articles were relevant with the topic. Several studies had reported the success of transnasal endoscopic choanal atresia repair with the use of stents. Study by Abdul-Cader et al. ${ }^{5}$ analyzed fifteen patient records, 10 females and 5 males, ages varying from newborns up to 14 years old with unilateral and bilateral choanal atresia. Majority of cases were diagnosed by paranasal sinus CT scan. The surgical correction was executed with endoscopic intranasal choanaplasty, instead of radical palatal approach, causing less morbidity and higher success rate.

Another study by Elsherif et al. ${ }^{8}$ reported twelve congenital choanal atresia (CCA) patients that were treated between 2008 and 2010. They found that transnasal endoscopic technique was the approach of choice for congenital choanal atresia repair because of good visualization of the posterior choana and the ability to fix the defect with a high surgical success rate. Eladl et al. ${ }^{6}$ reported 112 pediatric patients with congenital bilateral choanal atresia who underwent endoscopic repair. They reviewed that the surgical procedure was a safe and effective technique with minimal complication. The usage of endoscopy served better visualization and higher accessibility for the surgical instruments.

Wolf et al. ${ }^{9}$ retrospectively studied the cases of pediatric patients aged less than 18 years, with unilateral and bilateral choanal atresia, who underwent endoscopic surgery with or without stents from 2001 to 2012. The result reported $100 \%$ patency rate in both groups, with no significant differences. The study concluded that outstanding postoperative results could be accomplished both with and without stents. The use of stents were recommended in newborns to prevent immediate restenosis and subsequent potential life threatening complications. In older patients ( $>$ 1year) with relatively mild symptoms, the authors did not recommend the application of choanal stent.

\section{DISCUSSION}

Choanal atresia is a developmental anomaly of upper airway passage, where there is an occlusion between nasal cavity and nasopharynx. It was first described by Roederer in $1755 .{ }^{4}$ It is a rare congenital disorder occurring approximately one in 5000-7000 live births. ${ }^{1,10}$ Male to female ratio of CCA occurrence is $1: 2$, and unilateral atresia is more common than bilateral. Choanal atresia itself could be classified as bony, purely membranous, and mixed bony and membranous. There are various theories pertaining to the etiopathogenesis of choanal atresia. The most likely accepted theories are, either failure of oronasal membrane rupture which provides communication of nasal cavity and nasopharynx, or abnormal migration of neural crest cells into the nasal vault. Though some cases are hereditary suggesting monogenic inheritance, the majority cases are sporadic. ${ }^{11}$ Bilateral congenital choanal atresia causes complete nasal obstruction, leading to immediate respiratory distress and fatality due to asphyxia and cardiopulmonary arrest. This is because newborns are obligate nose breathers, who instinctively breathes only through the nose until approximately 4-6 weeks at which time mouth breathing is learned. ${ }^{12}$ It has been demonstrated that the relatively higher position of the cervical viscera during infancy impedes access of air from the mouth to the lower airway, thus leaving nose only for respiration. This may play a protective role against the aspiration of food in the newborn. The typical clinical picture of CCA is cyclic cyanosis i.e. blue spells and respiratory difficulty that worsens during feeding or when the baby falls asleep with mouth closed. This respiratory difficulty is relieved while 
crying, as the mouth opens. As CCA is very rare, it requires high level of suspicion, to detect and make it as a differential diagnosis. The diagnosis in our case was made when the nasogastric tube failed to pass through both the nares down to oropharynx, and it was confirmed by nasal endoscopy and also by CT scan. Although most cases of CCA are isolated, but the association with other congenital anomalies is already recognized. Thus, a comprehensive general physical examination is mandatory, to identify other congenital anomalies. It is also essential to assess anatomic and nasal deformity by nasal and pharyngeal examination using flexible or rigid endoscopes. The location, type and thickness of atresia are confirmed by axial plane CT scan. It could help the ENT surgeon in establishing the repair treatment plan including the associated abnormalities, such as high arched hard palate, thickened vomer, septum and lateral nasal structure deformities. The ultimate goal of choanal atresia surgery is complete removal of the atretic plate and assurance of longterm wide choanal patency. Out of various approaches for opening the choana, the transseptal, transpalatal and the endoscopic transnasal approaches are more commonly implemented. There are many factors to be considered in order to decide which particular approach will be applied..$^{13}$ Transnasal endoscopic procedure for choanal atresia is the preferred measure, while transpalatal approach is reserved for patients who are unfeasible to undergo transnasal surgery $(82.1 \%) .^{14}$

The success of choanal atresia repair depends on the operation as well the absence of or minimal postoperative complications. The choice of using stent or without had been widely discussed in the literature. Although there is no consensus in stent usage, certain factors are known to increase the chance of success with minimal complications, such as the choice of the stent material, the stenting duration, and patient's age. The most common complications after choanal atresia surgical correction are restenosis and granulation tissue. Some studies had suggested that the use of soft material stents could reduce the complications rather than using traditional stents. The duration of follow-up should be long term, at least one year (100\%): one year $(20 \%)$, to adulthood $(33.3 \%)$, two years being the most consensual $(46.7 \%)$. The surgical result is considered as stable after 6-12 months $(73.3 \%)$, but delayed restenosis had been described and this information should be given to the parents of the patients. ${ }^{15}$

Bilateral choanal atresia is a rare disorder and it should be suspected in newborn with a history of cyclical cyanosis. We reported a case of 2 months old baby girl with bilateral choanal atresia.mDiagnosis was established by CT scan and nasal endoscopy. She underwent transnasal endoscopic resection of the stenotic choanae under general anesthesia. A nasogastric tube was placed intranasally through the choanae into oropharynx bilaterally as stents. There were no intraoperative nor postoperative complications.

\section{REFERENCE}

1. Lazar RH, Younis RT. Transnasal repair of choanal atresia using telescopes. Arch Otolaryngol Head Neck Surg. 1995; 121: 517-20.

2. Kwong KM. Current Updates on Choanal Atresia. Front Pediatr. 2015; 3:52.

3. Heneger AS, Strom M. Choanal atresia: A new embryonic theory and its influence on surgical management. Laryngoscope. 2009; 92: 913-21.

4. Leclerc JE, Fearon B. Choanal atresia and associated anomalies. Int J Pediatr Otorhinolaryngol. 1987; 13: 265-72.

5. Abdul Cader SH et al. Clinical retrospective analysis of 15 cases of choanal atresiaOur experience. World Journal of Otorhinolaryngology-Head and Neck Surgery. 2019;1-5. https://doi.org/10.1016/j. wjorl. 
6. Eladl, H. M., Khafagy, Y. W. Endoscopic bilateral congenital choanal atresia repair of 112 cases, evolving concept and technical experience. International Journal of Pediatric Otorhinolaryngology. 2016;85, 40-5.

7. Ramsden JD, Campisi P, Forte V: Choanal atresia and choanal stenosis. Otolaryngol Clin North Am. 2009; 42: 339-52. 10.1016/j. otc. 2009.01 .00

8. Elsherif A, Osman Y, Abdelmoghny A, Mahrous A. Endonasal repair of choanal atresia, does stenting have a better outcome? Egyptian Society of Ear, Nose, Throat and Allied Sciences. 2012; 13:13-17

9. Wolf G, Thurnher D, Stammberger H, Tomazic PV: Are stents beneficial in endoscopic choanal atresia repair of newborns and children? Case series of 11 patients. Clin Otolaryngol. 2016; 41:821-25. 10.1111/coa.12566.

10. Samadi DS, Shah UK, Handler SD. Choanal atresia: a twenty year review or medical comorbidities and surgical outcomes. Laryngoscope. 2003; 113: 254-58.

11. Dunham ME, Miller RP. Bilateral choanal atresia associated with malformation of the anterior skull base: embryogenesis and clinical considerations. Ann Otol Rhinol Laryngol. 1992; 101: 916-19.

12. Harris J, Robert E, Kallen B. Epidemiology of choanal atresia with special refence to the CHARGE association. Pediatrics. 1997; 99: 363-67.

13. Williams HJ. Posterior choanal atresia. The American J of Roentgenology. 1971; 112: $1-11$.

14. Assanasen P, Metheetrairut C. Choanal Atresia. J Med Assoc Thai. 2009; 92: 699706.

15. Moreddu E, Rizzi M, Adil E, et al. International Pediatric Otolaryngology Group (IPOG) consensus recommendations: Diagnosis, pre-operative, operative and postoperative pediatric choanal atresia care. Int J Pediatr Otorhinolaryngol. 2019; 123:151-5. 